\title{
Purification and Characterization of Acid Phosphatases with or without Phytase Activity from Rice Bran
}

\author{
Toshiro Hayakawa, Yoshiaki Toma* and Ikuo Igaue \\ Department of Agricultural Chemistry, Faculty of Agriculture, \\ Nigata University, Ikarashi 2-8050, \\ Niigata 950-21, Japan \\ Received October 19, 1988
}

\begin{abstract}
The phytases (EC 3.1.3.26) and acid phosphatases (EC 3.1.3.2) of rice bran were purified. Four acid phosphatases were purified from rice bran: F1 and F2 had phytase activity, but F3 and F4 did not. The optimum $\mathrm{pH}$ of $\mathrm{F} 1$ and $\mathrm{F} 2$ for phytic acid were 4.4 and 4.6, respectively, and those of F1, F2, F3, and $\mathbf{F} 4$ for $\rho$-nitrophenyl phosphate were 5.1, 5.2, 5.4, and 6.0, respectively. Their molecular weights were estimated to be about $59 \sim 70 \mathrm{~K}$ by SDS polyacrylamide gel electrophoresis, velocity density gradient centrifugation, and gel filtration on Ultrogel. The isoelectric points of F1, F2, F3, and F4 were 5.1, 5.1, 5.6, and 5.9, respectively. F1, F2, F3, and F4 had a violet color and $F 2$ showed an absorption maximum peak at $560 \mathrm{~nm}$. They had broad substrate specificities.
\end{abstract}

Phytic acid (IHP) or myo-inositol 1,2,3,4,5,6-hexakis(dihydrogen phosphate) is widespread in nature, and the prinicipal from of phosphorus in many seeds. In cereals and meals, IHP is regarded as antinutritive factor. In rice seeds, the phosphorus of IHP represent up to $78 \%$ of the total phosphates. ${ }^{1)}$ Phytase (myo-inositol hexaphosphate phosphohydrolase) hydrolyzing IHP to inositol and inorganic phosphrous $(\mathrm{Pi})$ is widely distributed in plants, animals, and microorganisms. ${ }^{2)}$ In 1907, Suzuki et al. ${ }^{3)}$ found an enzyme in rice bran, and they tried to purify the enzyme but with little success. Later, the nature of phytases from soy bean, ${ }^{4}$ dwarf beans, ${ }^{5)}$ lettuce seeds, ${ }^{6)}$ wheat bran, $\left.{ }^{7} \sim 10\right)$ mung beans, ${ }^{11)}$ isolated aleurone particles of rice grains, ${ }^{12)}$ pumpkins, ${ }^{13)}$ pollen, ${ }^{14,15)}$ and barley ${ }^{16)}$ has been reported. However, enzyme preparations of sufficent purity suitable for characterization and structural studies have up to now been unavailable.

In this study, we describe the purification and some properties of acid phosphatases with or without phytase activity from rice bran.

\section{Materials and Methods}

Sample preparation. Rice bran of the strain Koshihikari, Oryza sativa L. Japonicas was provided by Niigata Kennbei $\mathrm{Co}$. The samples were stored at about $1 \sim 4^{\circ} \mathrm{C}$.

Enzyme assay. Phytase activity was assayed in a $0.5 \mathrm{ml}$ reaction mixture containing $250 \mu \mathrm{l}$ of $0.2 \mathrm{M}$ acetate buffer pH 4.6, $50 \mu \mathrm{l}$ of $100 \mathrm{~mm} \mathrm{Na-IHP}$, and $200 \mu \mathrm{l}$ of enzyme solution. The reaction mixture was incubated at $40^{\circ} \mathrm{C}$ for $60 \mathrm{~min}$, and the reaction was stopped by adding $0.5 \mathrm{ml}$ of $10 \%$ trichloroacetic acid solution, and the liberated Pi was measured by the method of Fisk and Subbarow. ${ }^{17)}$ One unit of enzyme activity is defined as the amount of enzyme which liberates $1 \mu \mathrm{mol}$ of Pi from substrate per hour under the assay conditions. The assay of acid phosphatase activity was as described in our previous paper. ${ }^{18}$ Protein was estimated from the absorbance at $280 \mathrm{~nm}$, and by the method of Lowry et al. ${ }^{191}$

Chemicals. Na-IHP was prepared by the precedure of Nagai and Funahashi. ${ }^{7)} \rho$-Nitrophenyl phosphate (Npp), $\alpha$-naphthyl phosphate, and Fast Garnet GBC were obtained from Nakarai Chemicals Ltd., DEAE-Cellulose, and P-Cellulose from Brown Co., and DEAE-Sephadex, CM-Sephadex, Sephadex G-150, Con-A Sepharose, and Blue dextran 2000 from Pharmacia. Ultrogel AcA 34 and Ampholine were obtained from LKB. Standard proteins were purchased from Boehringer. All other reagents were 
of analytical grade.

Electrophoresis. Analytical polyacrylamide gel electrophoresis (PAGE) was done at $\mathrm{pH} 8.9$ by the method of Davis. ${ }^{20)}$ Sodium dodecyl sulfate polyacrylamide gel electrophoresis (SDS-PAGE) was done by the method of Laemmli except for using $2.7 \mathrm{M}$ urea. ${ }^{21}$ )

Velocity density gradient centrifugation. A linear $5 \sim 10 \%$ glycerol density gradient $(4.6 \mathrm{ml})$ in $0.05 \mathrm{M}$ sodium acetate buffer ( $\mathrm{pH} \mathrm{5.1)}$ was prepared by the method of Martin and Ames. ${ }^{22)}$ The activity peaks were located by monitering the phytase and phosphatase activities. The $S$ value given is the average of the values obtained with different standards.

Estimation of molecular weight. Molecular weights of the purified enzymes were estimated by SDS-PAGE, ${ }^{21)}$ velocity density gradient centrifugation, ${ }^{22}$ and Ultrogel AcA 34 chromatography by the method of Andrews. ${ }^{23)}$

Isoelectric focusing. Isoelectric focusing was done in a $110 \mathrm{ml}$ column (LKB-produkter) using 1\% carrier ampholytes with a $\mathrm{pH}$ range of $4 \sim 6$. The density gradient in an electrofucusing column was formed with glycerol, and electrofocusing was done at $800 \mathrm{~V}$ and $2^{\circ} \mathrm{C}$ for $48 \mathrm{hr}$.

\section{Purification of acid phosphatase with phytase activity}

Step 1. Preparation of crude juice. All operations were at $0 \sim 4^{\circ} \mathrm{C}$. Uniess otherwise stated. Rice bran of $6.8 \mathrm{~kg}$ was homogenized in $18 \mathrm{l}$ distilled water with a rotary mixer for $1 \mathrm{hr}$. The homogenate was strained through four layers of gauze and centrifuged at $8000 \times g$ for $20 \mathrm{~min}$. The floating fraction was excluded by three layers of gauze.

Step 2. Ammonium sulfate fractionation. Solid ammonium sulfate was added to the supernatant solution to $30 \%$ saturation; the mixture was kept for $30 \mathrm{~min}$ and centrifuged at $8000 \times g$ for $20 \mathrm{~min}$. The supernatant was raised to $70 \%$ saturation of ammonium sulfate. The precipitate was dissolved in a small volume of distilled water, and dialyzed for $48 \mathrm{hr}$ in distilled water. The dialyzate was centrifuged to remove the inactive protein. The supernatant was purified further.

Step 3. DEAE-Cellulose column chromatography. The enzyme solution (total phytase activity: 108,700 units, acid phosphatase activity: $4,012,000$ units) was put on a column $(7 \times 100 \mathrm{~cm})$ of DEAE-Cellulose equilibrated with $0.01 \mathrm{M}$ Tris- $\mathrm{HCl}$ buffer $\mathrm{pH} 7.5$. The column was thoroughly washed with the same buffer and the adsorbed enzyme was eluted from the column with a linear gradient of 61 of the same buffer in the mixing chamber and 61 of the buffer containing $0.5 \mathrm{M} \mathrm{NaCl}$ in the reservoir. Acid phosphatase with phytase activity was detected in fractions $100 \sim 180$ and acid phosphatase without phytase activity in fractions $210 \sim 360$. Fractions $100 \sim 180$ were brought to $75 \%$ saturation with solid ammonium sulfate. After for $1 \mathrm{hr}$, the precipitate formed was collected by centrifugation.
Step 4. P-Cellulose chromatography. The precipitate was dialyzed overnight against 10 liters of $0.01 \mathrm{M}$ acetate buffer, $\mathrm{pH} 4.5$, containing $0.01 \%$ Triton X-100. The dialyzate was put on a column of P-Cellulose $(5.6 \times 95 \mathrm{~cm})$, which was equilibrated with the same buffer. The column was first washed with two vols. of the same buffer, then eluted with a linear gradient of 31 of the same buffer in the mixing chamber, and $3 \mathrm{l}$ of the buffer containing $0.5 \mathrm{M}$ $\mathrm{NaCl}$ in the reservoir. Fractions of $20 \mathrm{ml}$ were collected. The acid phosphatase with phytase activity (fractions $310 \sim 350$ ) was concentrated by an Advantic Ultrafilter, $\mathrm{N}-25$, and dialyzed against $0.01 \mathrm{M}$ acetate buffer, $\mathrm{pH} 5.5$, containing $0.01 \%$ Triton X-100.

Step 5. Con-A Sepharose chromatography. The dialyzed solution was adsorbed on a Con-A Sepharose column $(2 \times 30 \mathrm{~cm})$ equilibrated previously with $0.01 \mathrm{~m}$ acetate buffer, pH 5.5, containing $0.01 \%$ Triton X-100. The column was washed thoroughly with the same buffer to remove unadsorbed protein. The adsorbed proteins were eluted with a linear gradient of 0.71 of the same buffer in the mixing chamber and 0.71 of the buffer containing $0.2 \mathrm{M}$ methyl- $\alpha$-D-glucoside in the reservoir. Fractions of $10 \mathrm{ml}$ were collected. The acid phosphatase with phytase activity was resolved into two peaks ( $F 1$ and $F 2$ ) eluting at $0.05 \mathrm{M}$ and $0.1 \mathrm{M}$ methyl $\alpha$-D-glucoside contained in the buffer; those peaks were pooled and concentrated to about $2 \mathrm{ml}$ in a collodion bag (Sartorius $\mathrm{Co}$ ). The concentrated enzymes were a violet color.

Step 6. Gel filtration on Sephadex G-150. Fractions F1 and $F 2$ were each passed through a column $(2.5 \times 105 \mathrm{~cm})$, which had been equilibrated with $0.05 \mathrm{M}$ acetate buffer, $\mathrm{pH}$ 5.0 , containing $0.1 \mathrm{M} \mathrm{NaCl}$ and $0.05 \%$ Triton X-100. The elution profiles of the phytase activity and of the acid phosphatase activity were identical.

Step 7. CM-Sephadex C-50 Chromatography. The concentrated fraction of FI from Step 6 was put on a column $(1.7 \times 30 \mathrm{~cm})$ of CM-Sephadex C-50 equilibrated with $0.01 \mathrm{M}$ acetate buffer, $\mathrm{pH} 4.6$, containing $0.01 \%$ Triton $\mathrm{X}$ 100. Elution was done with a linear gradient of $300 \mathrm{ml}$ of the same buffer and $300 \mathrm{ml}$ of the buffer containing $0.5 \mathrm{M}$ $\mathrm{NaCl}$. Fractions of $5 \mathrm{ml}$ were collected. Fractions $93 \sim 102$ were pooled and condensed by a collodion bag. The F2 fraction was put on the column and eluted with the buffer, changing the $\mathrm{pH}$ from 4.6 to 4.9 with the acetate buffer. Fractions $110 \sim 135$ were combined and concentrated with a collodion bag.

Step 8. Second gel filtration through Sephadex G-150. The concentrated $\mathrm{F} 1$ and $\mathrm{F} 2$ were passed through a column $(1.5 \times 100 \mathrm{~cm})$ equilibrated with acetate buffer, $\mathrm{pH} 5.0$, containing $0.1 \mathrm{M} \mathrm{NaCl}$ and $0.05 \%$ Triton $X-100$. The elution patterns of phytase activity, phosphatase activity, and protein from F1 and F2 were symmetrical. These preparations were used for all subsequent experiments on $F 1$ and $F 2$.

Purification of acid phosphatase without phytases

Step 4'. CM-Sephadex C-50 chromatography. The frac- 


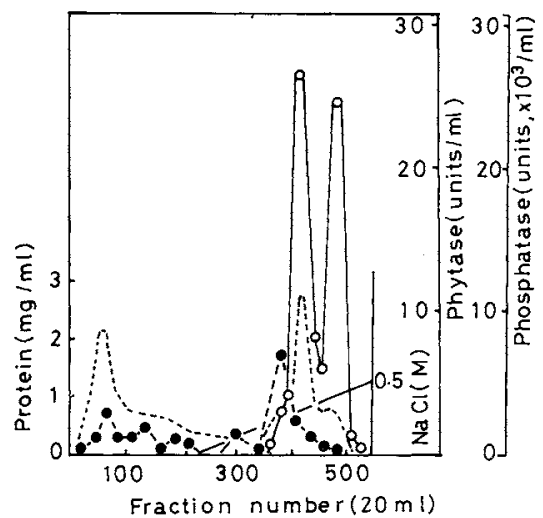

Fig. 1. CM-Sephadex Column Chromatography of the Acid Phosphatase without Phytase Activity from Rice Bran.

The dialyzate of ammonium sulfate precipitates from DEAE-Cellulose column chromatography (fractions $210 \sim 360)$ was put on a CM-Sephadex column $(4 \times 90 \mathrm{~cm})$ and eluted prep. a linear gradient of $\mathrm{NaCl}$ in the loading buffer. We designated the first peak as fraction F3 (No. $400 \sim 450$ ) and the second peak as fraction F4 (No. $470 \sim 510$ ).

- $\mathrm{O}$-, acid phosphatase activity without phytase activity; - - acid phosphatase with phytase activity; ---- , protein;,$- \mathrm{NaCl}$ concentration.

tions $(210 \sim 360)$ of DEAE-Cellulose chromatography in step 3 were brought to $75 \%$ saturation with solid ammonium sulfate. The precipitate formed was collected by centrifugation and was dialysed against 101 of $0.01 \mathrm{M}$ acetate buffer, pH 5.1, containing $0.01 \%$ Triton X-100. The dialyzate (acid phosphatase activity: 1,535,000 units) was put on a column of CM-Sephadex C $-50(4 \times 90 \mathrm{~cm})$, which was equilibrated with the same buffer. The column was washed with the same buffer. The adsorbed proteins were eluted with a linear gradient of $\mathrm{NaCl}$ from 0 to 0.5 M using the same buffer. The acid phosphatase without phytase activity was separated into $F 3$ and F4 fractions (Fig. 1). The fractions of F3 $(400 \sim 450)$ and F4 $(470 \sim 510)$ were pooled and brought to $80 \%$ ammonium sulfate saturation. After standing for $30 \mathrm{~min}$, the fractions were precipitated by centrifugation for $20 \mathrm{~min}$ with $8000 \times \mathrm{g}$.

Step 5'. 2nd CM-Sephadex chromatography. The precipitated F3 fraction of 1 st CM-Sephadex chromatography was dialysed against $0.01 \mathrm{M}$ acetate buffer, $\mathrm{pH} 5.2$, containing $0.01 \%$ Triton X-100. The dialysed enzymes were put on to a CM-Sephadex column $(3 \times 30 \mathrm{~cm})$, previously equilibrated with the same buffer, and the column was washed with the same buffer. The active fraction was eluted from the column, however, much inactive proteins was adsorbed. The eluted active fraction of F3 was concentrated by an Advantic Ultrafilter, N-25. The chromatography of $\mathrm{F} 4$ fraction was done by the same methods as for $\mathrm{F} 3$ fraction and the active fraction of $\mathrm{F} 4$ was not adsorbed by the column. The eluted F4 fraction was concentrated by the same methods as the F3 fraction.

Step 6'. Con-A Sepharose chromatography of F3. The concentrated $\mathrm{F} 3$ fraction was put on a column of Con-A Sepharose $(2 \times 30 \mathrm{~cm})$ which was equilibrated with $0.01 \mathrm{M}$ acetate buffer, pH 5.5, containing $0.01 \%$ Triton X-100. The column was washed throughly with the same buffer. The adsorbed protein was eluted with a linear gradient consisting $0 \sim 0.1 \mathrm{M}$ borate buffer containing $0.01 \%$ Triton $\mathrm{X}$ 100. The active fractions of F3 were concentrated by an Advantic Ultrafilter, $\mathrm{N}-25$.

Step 7'. Sephadex G-150 gel chromatography of F3. The concentrated F3 fraction was put on a column of Sephadex G-150 column $(2 \times 100 \mathrm{~cm})$, equilibrated with $0.01 \mathrm{M}$ acetate buffer, $\mathrm{pH} 5.0$, containing $0.1 \mathrm{M} \mathrm{NaCl}$ and $0.01 \%$ Triton X-100. The elution pattern of acid phosphatase activity, as well as of protein, was symmetrical. The preparation was used for all subsequent experiments on $\mathrm{F} 3$.

Step 7". First DEAE-Sephadex A-50 chromatography of $F 4$. The concentrated F4 fraction of Step $5^{\prime} \mathrm{CM}$-Sephadex column was put on a DEAE-Sephadex C-50 column $(2 \times 30 \mathrm{~cm})$ which was preequilibrated with $0.01 \mathrm{M}$ Trismaleate buffer, pH 6.8, containing $0.01 \%$ Triton $\mathrm{X}-100$. The adsorbed protein was eluted with a linear gradient consisting of $0 \sim 0.4 \mathrm{M} \mathrm{NaCl}$ in the same buffer. The active fractions were concentrated with an Advantic Ultrafilter, $\mathrm{N}-25$.

Step 8". 2nd DEAE-Sephadex A-50 column chromatography of $F 4$. The $\mathrm{F} 4$ fraction was put on a column of DEAE-Sephadex $(1 \times 30 \mathrm{~cm})$ equilibrated with $0.01 \mathrm{M}$ Tris-maleate buffer, $\mathrm{pH} 6.8$, containing $0.01 \%$ Triton $\mathrm{X}$ 100. The adsorbed F4 fraction was eluted by the same method as in Step 7". This preparation was used for all subsequent experiments on $\mathrm{F} 4$.

\section{Results}

\section{Purifications}

The enzyme activities were separated by DEAE-Cellulose chromatography into two major peaks: fractions $100 \sim 180$ (maximum peak at 150 ) were acid phosphatases with phytase activities, but factions $210 \sim 360$ (maximum peak at 260) were acid phosphatases without phytase activities. In Con-A Sepharose affinity chromatography, the acid phosphatase with phytase activity was resolved into two fractions, F1 and F2. Sephadex G-150 and CM-Sephadex chromatographies could not separate the phytase activity from acid phosphatase activity. Acid phosphatase without phytase activity, F3 and F4, were adsorbed on a CM-Sephadex column at $\mathrm{pH}$ 
Table I. Purification of Acid Phosphatase with Phytase F1 and F2 from Rice Bran

\begin{tabular}{|c|c|c|c|c|c|c|c|c|c|c|c|}
\hline \multirow[b]{2}{*}{ Procedure } & \multicolumn{6}{|c|}{ Phytase activity } & \multicolumn{5}{|c|}{ Acid phosphatase activity } \\
\hline & Fractions & $\begin{array}{c}\text { Protein } \\
(\mathrm{mg})\end{array}$ & $\begin{array}{c}\text { Total } \\
\text { activity } \\
\text { (units) }\end{array}$ & $\begin{array}{c}\text { Specific } \\
\text { activity } \\
\text { (units/mg) }\end{array}$ & $\begin{array}{c}\text { Recovery } \\
(\%)\end{array}$ & Purification & $\begin{array}{l}\text { Total } \\
\text { activity } \\
\text { (units) }\end{array}$ & $\begin{array}{c}\text { Specific } \\
\text { activity } \\
\text { (units/mg) }\end{array}$ & Recovery & Purification & $\begin{array}{l}\text { Phytase } \\
\text { activity } \\
(\%)^{a}\end{array}$ \\
\hline Water extract & & 205,700 & 295,300 & 1.4 & 100 & 1 & $7,211,900$ & 35 & 100 & 1 & 4.0 \\
\hline $\begin{array}{l}\left(\mathrm{NH}_{4}\right)_{2} \mathrm{SO}_{4} \\
30 \sim 70 \% \text { sat. }\end{array}$ & & 37,160 & 108,700 & 2.9 & 36.7 & 2 & $4,012,000$ & 108 & 55.6 & 3.1 & 2.7 \\
\hline DEAE-Cellulose & $\mathrm{F} 1,2$ & 6770 & 44,050 & 6.5 & 14.9 & 5 & $8,604,780$ & 127 & 11.9 & 3.6 & 5.1 \\
\hline P-Cellulose & $\mathrm{F} 1,2$ & 440.8 & 34,590 & 78.5 & 11.7 & 54 & 507,930 & 1152 & 7.0 & 32.8 & 6.8 \\
\hline Con A & $\mathrm{Fl}$ & 21.8 & 10,190 & 466.7 & 3.5 & 324 & 149,160 & 6832 & 2.1 & 194.6 & 6.8 \\
\hline Sepharose & $\mathrm{F} 2$ & 22.7 & 11,390 & 502.8 & 3.9 & 349 & 191,380 & 8431 & 2.7 & 240.2 & 5.9 \\
\hline 1st Sephadex & F1 & 13.9 & 8920 & 641.5 & 3.0 & 446 & 169,430 & 12,189 & 2.4 & 347.3 & 5.3 \\
\hline $\mathrm{G}-150$ & $\mathrm{~F} 2$ & 7.0 & 7440 & 1070.9 & 2.5 & 744 & 141,420 & 20,347 & 2.0 & 579.7 & 5.3 \\
\hline CM-Sephadex & $\mathrm{F} 1$ & 1.6 & 3920 & 2390.2 & 1.2 & 1707 & 74,480 & 45,415 & 1.0 & 1294.0 & 5.3 \\
\hline C-50 & $\mathrm{F} 2$ & 2.6 & 6210 & 2388.0 & 2.1 & 1706 & 111,780 & 42,992 & 1.6 & 1224.9 & 6.6 \\
\hline 2nd Sephadex & $\mathrm{F} 1$ & 1.0 & 3030 & 3030.0 & 1.0 & 2164 & 56,500 & 56,500 & 0.8 & 1609.7 & 5.4 \\
\hline$G-150^{\circ}$ & $\mathrm{F} 2$ & 1.3 & 3505 & 2696.0 & 1.2 & 1926 & 61,300 & 47,154 & 0.9 & 1343.4 & 5.7 \\
\hline
\end{tabular}

a Shows $\%$ of specific phytase activity to specific acid phosphatase activity in F1 and F2. 
Table II. Purification of Acid Phosphatase without Phytase F3 and F4 from Rice Bran ${ }^{a}$

\begin{tabular}{lccccrr}
\hline Procedure & Fractions & $\begin{array}{c}\text { Protein } \\
\text { (mg) }\end{array}$ & $\begin{array}{c}\text { Total activity } \\
\text { (units) }\end{array}$ & $\begin{array}{c}\text { Specific activity } \\
\text { (units/mg) }\end{array}$ & $\begin{array}{c}\text { Recovery } \\
\text { (\%) }\end{array}$ & Purification \\
\hline DEAE-Cellulose & F3, F4 & 12,980 & $1,535,000$ & 118.4 & 21.3 & 3.4 \\
1st CM-Sephadex & F3 & 706.7 & 233,100 & 329.8 & 3.2 & 9.4 \\
2nd CM-Sephadex & F4 & 866.9 & 633.200 & 730.7 & 20.8 & 20.9 \\
& F3 & 155.9 & 144,530 & 927.1 & 2.0 & 26.5 \\
Con-A Sepharose & F4 & 151.2 & 491.400 & 3250.0 & 6.8 & 92.9 \\
Sephadex G-150 & F3 & 4.0 & 49,900 & 12,470 & 0.7 & 350.4 \\
Ist DEAE-Sephadex & F3 & 0.8 & 35,000 & 43,750 & 0.5 & 1250.0 \\
2nd DEAE-Sephadex & F4 & 4.8 & 124,000 & 25,830 & 0.2 & 736.0 \\
\hline
\end{tabular}

a Purification procedure of these fractions were followed by $\left(\mathrm{NH}_{4}\right)_{2} \mathrm{SO}_{4}$ precipitation in Table I.

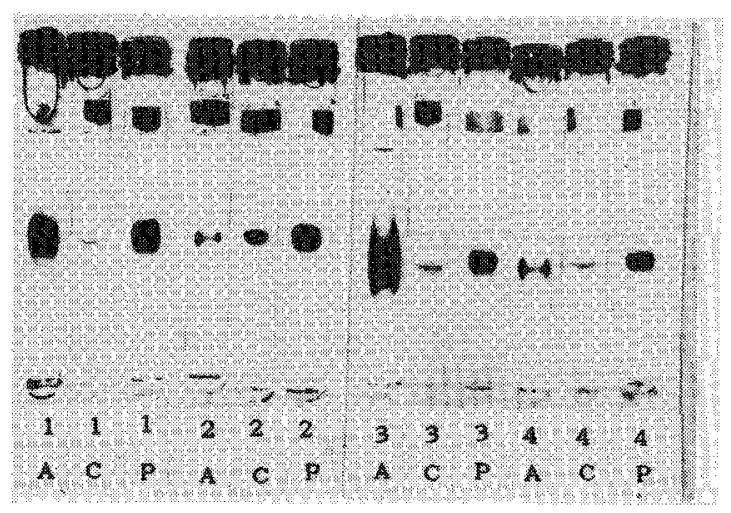

Fig. 2. PAGE of Purified Acid Phosphatase with Phytase Activity (F1 and F2) and Acid Phosphatase without Phytase Activity (F3 and F4).

One or two $\mu \mathrm{g}$ of protein were used for activity visualization and $30 \mu \mathrm{g}$ of protein were used for carbohydrate and protein staining. Symbols: A, activity; $\mathrm{C}$, carbohydrate; $\mathrm{P}$, protein; 1, F1; 2, F2; 3, F3; 4, F4.

5.1, however, at $\mathrm{pH} 5.2$, then were eluted from the column. The eluted enzymes were much purified by CM-Sephadex chromatography.

The yields of the enzymes were phytase activity of $\mathrm{F} 1,1 \%$ and of $\mathrm{F} 2,1.2 \%$, and the acid phosphatase activity of $\mathrm{F} 1,0.8 \%$ and $\mathrm{F} 2$, $0.9 \%$ (Table I). The yields of acid phosphatase activity $\mathrm{F} 3$ and $\mathrm{F} 4$ were only $0.5 \%$ (Table II). The enzyme activities are stable at $4^{\circ} \mathrm{C}$ for several months in the $0.01 \mathrm{M}$ acetate buffer, $\mathrm{pH}$ $5.0 \sim 7.0$, containing $0.01 \%$ Triton $\mathrm{X}-100$, in a cold room.

\section{$P A G E$}

As shown in Fig. 2, PAGE indicated that

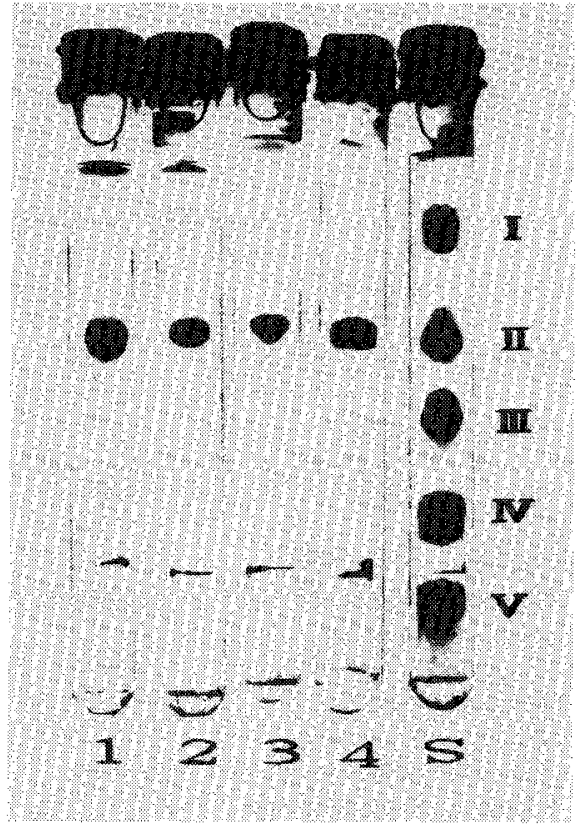

Fig. 3. SDS-PAGE of F1, F2, F3 and F4.

Electrophoreses were done in $10 \%$ polyacrylamide gel in 0.1 M sodium phosphate buffer ( $\mathrm{pH} 7.2$ ) containing $0.1 \%$ SDS. Before electrophoreses, samples containing $0.01 \mathrm{~m}$ phosphate buffer. $1 \%$ SDS, $1 \% 2$-mercaptoethanol, and about $20 \sim 30 \mu \mathrm{g}$ protein were incubated at $50^{\circ} \mathrm{C}$ for $2 \mathrm{hr}$. Lane 1, F1; 2, F2; 3, F3; 4, F4. Lane S: standards proteins: I, aldolase $(158 \mathrm{~K})$; II, bovine serum albumin $(67 \mathrm{~K})$; III, ovalbumin $(45 \mathrm{~K})$; IV, chymotripsinogen $(25 \mathrm{~K})$; V, cytochrome $c(12.4 \mathrm{~K})$.

F1, F2, F3, and F4 contained a single protein which had the phosphatases activity detected by the procedure of Ogita, ${ }^{24)}$ using $\alpha$-naphthylphosphate and Fast Blue B salt. All of these 


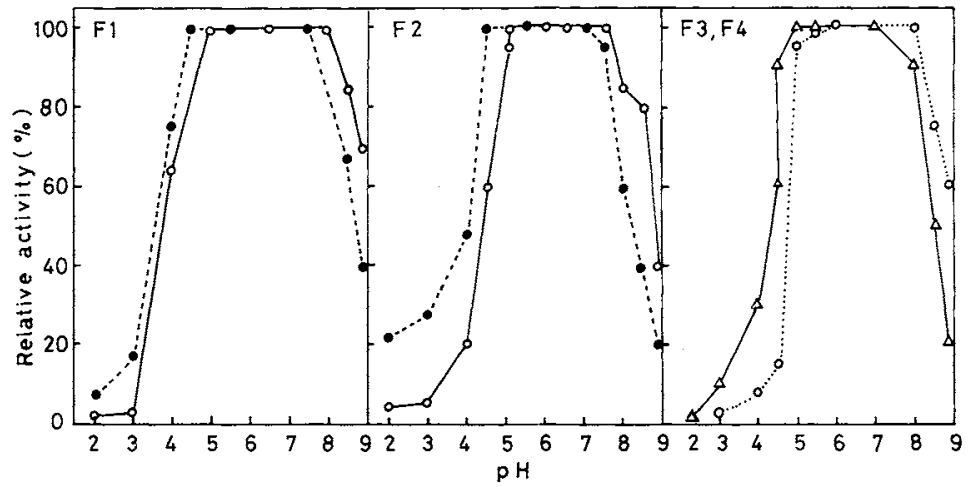

Fig. 4. Effects of pHs on the Stability of F1, F2, F3, and F4.

The enzyme solutions $(0.5 \mu \mathrm{g}$ of protein $/ \mathrm{ml})$ were kept at $4{ }^{\circ} \mathrm{C}$ for $24 \mathrm{hr}$ in $0.05 \mathrm{M}$ of each buffer. After the treatment, the enzyme solutions were diluted with $0.5 \mathrm{M}$ acetate buffer, $\mathrm{pH} 4.6$, (phytase activity of $\mathrm{F} 1$ and $\mathrm{F} 2$ ) and acetate buffer, pH 5.5, (acid phosphatases activity of F1, F2, F3, and F4), then remaining activities were assayed under the standard coditions. Symbols: $--\mathbf{-}_{--}$, phytase activity of $\mathrm{F} 1$ and $\mathrm{F} 2$; $-\mathrm{O}-$, acid posphatase activity of $\mathrm{Fl}$ and $\mathrm{F} 2 ;-\triangle-$, acid phosphatase activity of $\mathrm{F} 3 ;--\mathrm{O}_{---}$, acid phosphatase activity of F4.

Table III. Substrates Specificity of F1, F2, F3, And F4

\begin{tabular}{|c|c|c|c|c|c|c|}
\hline \multirow{2}{*}{$\begin{array}{l}\text { Enzyme preparation } \\
\mathrm{pH} \text { of the enzyme reactions }\end{array}$} & \multicolumn{2}{|c|}{$\mathrm{Fl}$} & \multicolumn{2}{|c|}{$\mathrm{F} 2$} & \multirow{2}{*}{$\frac{\mathrm{F} 3}{5.4}$} & \multirow{2}{*}{$\frac{\mathrm{F} 4}{6.0}$} \\
\hline & 4.4 & 5.2 & 4.6 & 5.2 & & \\
\hline Substrate $(10 \mathrm{~mm})$ & \multicolumn{6}{|c|}{ Relative activity $(\%)$} \\
\hline NPP & 100 & 100 & 100 & 100 & 100 & 100 \\
\hline IHP & 5.4 & 2.5 & 5.7 & 2.3 & 0 & 0 \\
\hline$\alpha$-Naphthyl phosphate & 24.5 & 35.0 & 41.0 & 48.2 & 31.5 & 34.0 \\
\hline$\beta$-Naphthyl phosphate & 29.4 & 71.2 & 59.6 & 75.5 & 75.0 & 78.6 \\
\hline$\alpha$-Glycerol phosphate & 5.1 & 4.3 & 3.6 & 3.3 & 13.6 & 14.9 \\
\hline$\beta$-Glycerol phosphate & 90.2 & 93.0 & 91.6 & 92.0 & 51.6 & 21.4 \\
\hline Glucose 1-phosphate & 61.9 & 100.0 & 5.1 & 10.6 & 10.0 & ND \\
\hline Glucose 6-phosphate & 7.0 & 7.5 & 5.1 & 5.0 & 6.0 & 15.1 \\
\hline Fructose 1,6-diphosphate & 8.0 & 7.0 & 9.2 & 9.5 & 17.0 & 28.8 \\
\hline Adenosine 5 'triphosphate & 51.1 & 64.0 & 66.7 & 73.5 & 52.0 & 41.6 \\
\hline Adenosine 5'-diphosphate & 13.3 & 16.2 & 11.5 & 16.0 & 17.0 & 19.1 \\
\hline Adenosine $5^{\prime}$-phosphate & 2.4 & 1.6 & 1.8 & 1.3 & 11.5 & 8.9 \\
\hline Inorganic pyrophosphate & 50.1 & 60.0 & 53.0 & 58.6 & 52.1 & 58.0 \\
\hline $\operatorname{Bis}(\rho$-nitrophenyl $)$ phosphate & 0 & 0 & 0 & 0 & 0 & 0 \\
\hline Adenosine $3^{\prime}, 5^{\prime}$-phosphate & 0 & 0 & 0 & 0 & 0 & 0 \\
\hline
\end{tabular}

protein bands were stained by the PAS reaction. ${ }^{25}$ )

\section{Physical properties}

Molecular weight of the purified enzymes were estimated by SDS-PAGE (Fig. 3), gel filtration on Ultrogel AcA 34, and velocity density gradient centrifugation: $\mathrm{F} 1,66 \mathrm{~K}$ by SDS, $61 \mathrm{~K}$ by Ultrogel filtration and $68 \mathrm{~K}$ by density gradient centrifugation; F2, $61 \mathrm{~K}$, $70 \mathrm{~K}$, and $68 \mathrm{~K} ; \mathrm{F} 3,61 \mathrm{~K}, 66 \mathrm{~K}$, and $66 \mathrm{~K}, \mathrm{~F} 4$, $60 \mathrm{~K}, 59 \mathrm{~K}$, and $68 \mathrm{~K}$. The molecular weight of the native enzymes was similar to that for SDS-PAGE. This suggested that F1, F2, F3, and $\mathrm{F} 4$ may be monomeric proteins. The isoelectric points of $\mathrm{F} 1, \mathrm{~F} 2, \mathrm{~F} 3$, and $\mathrm{F} 4$ were F1; 5.1, F2: 5.1, F3: 5.6, and F4: 5.9. The purified F1, F2, F3, and F4 had a violet color 


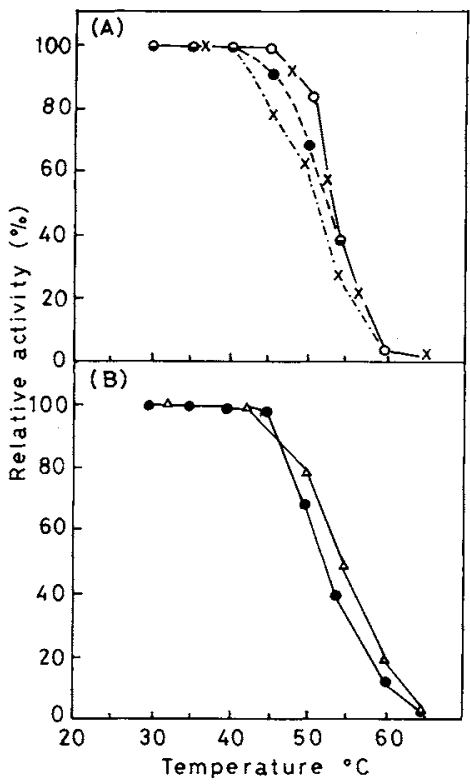

Fig. 5. Effects of Temperature on the stability of F1, F2, F3 and F4.

Enzyme preparations were incubated for $30 \mathrm{~min}$ at indicated temperatures in $0.05 \mathrm{M}$ acetate buffer, $\mathrm{pH} 5.5$. After the treatment, the enzyme solutions were diluted with $0.2 \mathrm{M}$ acetate buffer, $\mathrm{pH} 4.6$ (phytase activity of $\mathrm{Fl}$ and F2) and acetate buffer $\mathrm{pH} 5.5$ (acid phosphatase activity of $F 1, F 2, F 3$, and F4). The residual activity is expressed as a percentage of the control (not treated).

(A) symbols: - - , phytase activity of $\mathrm{F} 1 ;-\mathrm{O}-$, acid phosphatase activity of $\mathrm{F} 1 ; \cdot-\times-\cdot$, phytase activity of $F 2 ;-x-$, acid phosphatase activity of $F 2$.

(B): $-\triangle-$, acid phosphatase activity of $\mathrm{F} 3 ;-\mathrm{-}$, acid phosphatase activity of $\mathrm{F} 4$.

and $\mathrm{F} 2$ had a broad absorption peak at around $560 \mathrm{~nm}$ in $0.05 \mathrm{M}$ acetate buffer, pH. 5.5. We could not measure the absorption specta of F1, $\mathrm{F} 3$, and F4 because of their low yields.

\section{Effects of pH on the enzyme activity and} stability

The $\mathrm{pH}$-activity curve of phytase activities of F1 and F2 were a little different. The phytase activities had a narrow $\mathrm{pH}$-activity curve and were active at 4.4 for $\mathrm{F} 1$ and at 4.6 for $\mathrm{F} 2$. Acid phosphatase activities were broad $\mathrm{pH}-$ activity curves and were most active at 5.1 for $F 1$, at 5.2 for $F 2$, at 5.4 for $F 3$, and at 6.0 for F4. The pH-stability maxima were between $\mathrm{pH}$ $5.5 \sim 7.5$, however, below $\mathrm{pH} 4.5$, acid phos- phatase rapidly lost activity, but the phytase activity was stable at pH 4.5 (Fig. 4).

Effects of temperature on activity and stability

The optimum temperatures of the four enzymes were as follows: $40^{\circ} \mathrm{C}$ for phytase activity of $\mathrm{F} 1$ and $\mathrm{F} 2 ; 46^{\circ} \mathrm{C}, 50^{\circ} \mathrm{C}, 48^{\circ} \mathrm{C}$, and $50^{\circ} \mathrm{C}$ for acid phosphatase activity of $\mathrm{F} 1, \mathrm{~F} 2$, $\mathrm{F} 3$, and $\mathrm{F} 4$, respectively. Their thermal stabilities for the phytase activity of F1 and F2 retained $90 \%$ and $78 \%$ of their initial activity, and acid phosphatase activity of F1, F2, F3, and $\mathrm{F} 4$ retained $100 \%$ of the activity (Fig. 5).

\section{Substrate specificity}

The substrate specificity of F1, F2, F3, and $\mathrm{F} 4$ was investigated, and their optimum $\mathrm{pH}$ conditions (Table III). The substrate specificity of the enzymes were similar except for IHP and G-1-P. F1 and F2 were active against IHP, but F3 and F4 were not. F1 was inhibited by IHP above the concentration of $3 \mathrm{~mm}$ (data not shown). No phosphodiesterase activity was observed.

\section{Kinetic constants for IHP and NPP}

The $K m$ values for IHP and NPP were calculated Lineweaver-Burk plots. They were $0.17 \mathrm{~mm}(\mathrm{~F} 1)$ and $0.09 \mathrm{~mm}(\mathrm{~F} 2)$ for $\mathrm{IHP}$, $1.37 \mathrm{~mm}$ (F1), $1.33 \mathrm{~mm}(\mathrm{~F} 2), 0.83 \mathrm{~mm}(\mathrm{~F} 3)$, and $1.33 \mathrm{~mm}(\mathrm{~F} 4)$ for NPP.

\section{Effects of metal ions and chemical reagents on} enzyme activity

The effects of metal ions and chemical reagents on the enzyme activities were examined using IHP and NPP as the substrates. The results are shown in Table IV. The enzyme activities were strongly inhibited by $\mathrm{Mo}_{7} \mathrm{O}_{24}{ }^{6-}$ and $\mathrm{Ag}^{+}, \mathrm{Zn}^{2+}, \mathrm{Cu}^{2+}$, and $\mathrm{Hg}^{2+}$ also potently inhibited the acid phosphatase activity of $\mathrm{Fl}$ and F2, but phytase activities of these were only inhibited about $30 \sim 80 \%$. $\mathrm{Pi}$ and $\mathrm{F}^{-}$also caused inhibition. $\mathrm{ICH}_{2} \mathrm{COOH}$ and PCMB inhibited phytase activities of $\mathrm{F} 1$ and $\mathrm{F} 2$ and phosphatase activity of $\mathrm{Fl}$ but not the acid phosphatase activity of $\mathrm{F} 2, \mathrm{~F} 3$, and $\mathrm{F} 4 . \mathrm{Ca}^{2+}$ enhanced the phytase activity rather than the 
Table IV. Effects of Metal Ions and Several Inhibitors on F1, F2, F3, and F4

\begin{tabular}{|c|c|c|c|c|c|c|c|}
\hline \multirow{2}{*}{\multicolumn{2}{|c|}{ Fractions }} & \multicolumn{2}{|c|}{$\mathrm{F} 1$} & \multicolumn{2}{|c|}{$\mathrm{F} 2$} & \multirow{2}{*}{$\frac{F 3}{5.4}$} & \multirow{2}{*}{$\begin{array}{r}\mathrm{F} 4 \\
6.0\end{array}$} \\
\hline & & 4.4 & 5.2 & 4.6 & 5.2 & & \\
\hline \multicolumn{2}{|c|}{ Substrates of enzyme reactions } & IHP & $\mathrm{Npp}$ & IHP & $\mathrm{Npp}$ & $\mathrm{Npp}$ & $\mathrm{Npp}$ \\
\hline Substances & Concentration & \multicolumn{6}{|c|}{ Relative activity } \\
\hline None & & 100 & 100 & 100 & 100 & 100 & 100 \\
\hline $\mathrm{ZnSO}_{4}$ & $1 \mathrm{~mm}$ & 68 & 9 & 47 & 11 & 25 & 23 \\
\hline $\mathrm{CuSO}_{4}$ & 1 & 71 & 8 & 62 & 8 & 50 & 54 \\
\hline $\mathrm{HgCl}_{2}$ & 1 & 30 & 3 & 77 & 26 & 1 & 1 \\
\hline$\left(\mathrm{NH}_{4}\right)_{6} \mathrm{Mo}_{7} \mathrm{O}_{24}$ & 1 & 1 & 2 & 1 & 2 & 0 & 0 \\
\hline $\mathrm{CoCl}_{2}$ & 1 & 116 & 100 & 109 & 99 & 100 & 104 \\
\hline $\mathrm{NaF}$ & 1 & 72 & 77 & 69 & 66 & 60 & 70 \\
\hline Pi & 1 & 63 & 85 & 70 & 83 & 92 & 86 \\
\hline $\mathrm{Pi}$ & 10 & 15 & 44 & 20 & 30 & 50 & 60 \\
\hline $\mathrm{ICH}_{2} \mathrm{COOH}$ & 10 & 50 & 79 & 78 & 95 & 100 & 107 \\
\hline $\mathrm{PCMB}$ & 10 & 1 & 8 & 4 & 4 & 82 & 90 \\
\hline $\mathrm{AgNO}_{3}$ & 10 & 0 & 0 & 1 & 0 & 2 & 3 \\
\hline $\mathrm{CaCl}_{2}$ & 10 & 140 & 117 & 133 & 121 & 110 & 115 \\
\hline $\mathrm{MnCl}_{2}$ & 10 & 122 & ND & 116 & 101 & 95 & 99 \\
\hline $\mathrm{MgCl}_{2}$ & 10 & 115 & 100 & 110 & 100 & 108 & 111 \\
\hline EDTA & 10 & 114 & 108 & 110 & 106 & 98 & 100 \\
\hline Bipyridine & 10 & 102 & 103 & 100 & 100 & 99 & 97 \\
\hline$o$-Phenanthroline & 10 & 100 & 100 & 100 & 98 & 100 & 99 \\
\hline 8-Hydroxyquinoline & 10 & 114 & 110 & 105 & 106 & 101 & 98 \\
\hline$D(-)$ Tartrate & 10 & 115 & 116 & 108 & 106 & 104 & 100 \\
\hline $\mathrm{L}(+)$ Tartrate & 10 & 112 & 110 & 107 & 105 & 102 & 101 \\
\hline
\end{tabular}

acid phosphatase activity of F1, F2, F3, and F4. $\mathrm{Mn}^{2+}$ and $\mathrm{Mg}^{2+}$ had little effect on all the phytase activities of $F 1$, and $F 2$, and on the acid phosphatase activities of F1, F2, F3, and $\mathrm{F} 4$. The enzyme activities of F1 and F2 were slightly activated by EDTA, hydroxyquinoline, $\mathrm{D}(-)$ tartrate, and $\mathrm{L}(+)$ tartrate.

\section{Discussion}

In this paper, we attempted to clarify the nature of IHP hydrolysis by isolating enzymes which participate in the dephosphorylation of IHP in the rice bran. We could not separate an IHP specific enzyme from acid phosphatase with phytase activity from rice bran, and the phytase activity was always about $4 \sim 6 \%$ of that of acid phosphatase activity of $\mathrm{F} 1$ and $\mathrm{F} 2$. We also isolated acid phosphatases $\mathrm{F} 3$ and $\mathrm{F} 4$ which had no phytase activity. The enzymes were monomeric proteins and their molecular weights were slightly lower than that of the acid phosphatase from aleurone particles of rice grains. ${ }^{26)} \mathrm{F} 1, \mathrm{~F} 2, \mathrm{~F} 3$, and $\mathrm{F} 4$ had a violet color and the absorption peak of F2 was broad with a maximum at around $560 \mathrm{~nm}$. Similar acid phosphatases have been isolated from aleulone particles of rice grains, ${ }^{26)}$ sweet potato, ${ }^{27 \sim 30)}$ soybean, ${ }^{31)}$ and kidney bean. ${ }^{32)}$

In our previous papers, ${ }^{33,34)}$ we isolated violet-colored acid phosphatase isozymes from cultured cells of rice plants. The molecular weight of the cytoplasmic enzymes were $230 \mathrm{~K}$, composed of four subunits. Some properties of $\mathrm{F} 1$ and $\mathrm{F} 2$ resembled to those of the colored acid phosphatase prepared from the cultured cells in their $K m, p I$, absorption spectra, substrate specificities, and inhibitors except for the molecular weights. Presumably $59 \mathrm{~K} \sim 70 \mathrm{~K}$ of the colored acid phosphatases in this study were dissociated forms of the tetramer type of the cytoplasmic acid phosphatases from cul- 
tured cells of rice plants. The reported $\mathrm{pH}$ optimum of phytase from aleurone particles of rice grains was $4.5^{35}$ for IHP and that reported by Yamagata et al. was 4.8 for acid phosphatase with NPP as a substrate. IHP-specific phytases were separated from microorganisms ${ }^{36 \sim 38,42)}$ and plants. ${ }^{11,14,39,40)}$ Our enzymes from rice bran were nonspecific acid phosphatases. They are similar to the enzymes from wheat bran, ${ }^{7-10)}$ navy bean ${ }^{41)}$ and aleurone particles of rice rains. ${ }^{26)}$

\section{References}

1) F. Kurasawa, T. Hayakawa, I. Okamoto and S. Imai, Nippon Nōgeikagaku Kaishi, 43, 735 (1969).

2) D. J. Cosgrove, "Inositol phosphates," Elsevier Scientific Publishing Co., Amsterdam, 1980, pp. $85 \sim 98$.

3) U. Suzuki, K. Yoshimura and M. Takaishi, Bull. Coll. Agr. Tokyo Imper. Univ., 7, 503 (1907).

4) F. C. Mayer, R. E. Campbell, A. K. Smis and L. L. Mckinney, Arch. Biochem. Biophys., 94, 301 (1961).

5) L. N. Gibbins and F. W. Norris, Biochem. J., 86, 67 (1963).

6) A. M. Mayer, Enzymologia, 19, 1 (1958).

7) Y. Nagai and S. Funahashi, Agric. Biol. Chem., 26, 794 (1962).

8) Y. Nagai and S. Funahashi, Agric. Biol. Chem., 27, 619 (1963)

9) P. E. Lim and M. E. Tate, Biochim. Biophys. Acta, 250, 155 (1971).

10) P. E. Lim and M. E. Tate, Biochim. Biophys. Acta, 302, 316 (1973).

11) N. C. Mandal, S. Burman and B. B. Biswas, Phytochem., 11, 495 (1972).

12) T. Yoshida, K. Tanaka and Z. Kasai, Agric. Biol. Chem., 39, 289 (1975).

13) M. Goel and C. B. Sharma, Phytochem., 18, 1939 (1979).

14) A. Hara, S. Ebina. A. Kondo and T. Funaguma, Agric. Biol. Chem., 49, 3539 (1985).

15) J. Lin, D. B. Dickinson and T. D. Ho, Plant Physiol., 83, 408 (1987).

16) K. Gabard and R. L. Jones, Physiol. Plant, 67, 182 (1986).

17) C. H. Fisk and Y. Sabbarow, J. Biol. Chem., 66, 375
(1925).

18) I. Igaue, M. Nishio and F. Kurasawa, Agric. Biol. Chem., 37, 941 (1973).

19) O. H. Lowry, N. J. Rosebrough, A. L. Farr and R. J. Randall, J. Biol. Chem., 193, 265 (1951).

20) J. B. Davis, Ann. N. Y. Acad. Sci., 121, 404 (1964).

21) U. K. Laemmli, Nature, 227, 680 (1970).

22) R. G. Martin and B. N. Ames, J. Biol. Chem., 236, 1372 (1961).

23) P. Andrews, Biochem. J., 96, 595 (1965).

24) Z. Ogita, SABCO. J., 2, 91 (1966).

25) R. M. Zacharius, T. E. Zell, T. H. Morrison and J. J. Woodlock, Anal. Biochem., 30, 1481 (1969).

26) H. Yamagata, K. Tanaka and Z. Kasai, Plant Cell Physiol., 21, 1449 (1980).

27) K. Uehara, S. Fujimoto and T. Taniguchi, $J$. Biochem., 75, 627 (1974).

28) K. Uehara, S. Fujimoto, T. Taniguchi and K. Nakai, J. Biochem., 75, 639 (1974).

29) Y. Sugiura, H. Kawabe, H. Tanaka, S. Fujimoto and A. Ohara, J. Biol. Chem., 256, 10664 (1981).

30) S. K. Hefler and B. A. Averill, Biochem. Biophys. Res. Commun., 146, 1173 (1987).

31) S. Fujimoto, T. Nakagawa and A. Ohara, Agric. Biol. Chem., 41, 599 (1977).

32) J. L. Beck, L. A. Mcconachie, A. C. Summors, W. N. Arnild, J. D. Jersey and B. Zerner, Biochim. Biophys. Acta, 869, 61 (1986).

33) I. Igaue, H. Watabe, K. Takahashi, M. Takekoshi and A. Molota, Agric. Biol. Chem., 40, 823 (1976).

34) I. Igaue, Monbusho Kagakukenkyuhi Ippankenkyu B. Houkokusho, 1979, p. 27.

35) T. Yoshida, K. Tanaka and Z. Kasai, Agric. Biol. Chem, 39, 289 (1975).

36) V. K. Power and V. Jagannthan, J. Bacteriol., 151, 1102 (1982).

37) G. C. J. Irving and D. J. Cosgrove, Aust. J. Biol. Sci., 24., 547 (1971).

38) G. C. J. Irving and D. J. Cosgrove, Aust. J. Biol. Sci., 27, 361 (1974).

39) I. B. Maiti, A. L. Majumder and B. B. Biswas, Phytochemistry, 13, 1047 (1974).

40) I. B. Maiti and B. B. Biswas, Phytochemistry, 18, 316 (1979).

41) C. M. Lolas and P. Markakis, J. Food. Sic., 42, 1094 (1977).

42) A. H. J. Ullah and D. M. Gibson, Preparative Biochem., 17, 63 (1987). 